\title{
Direct Methanol Anion Exchange Membrane Fuel Cell with a Non-Platinum Group Metal Cathode based on Iron-Aminoantipyrine Catalyst
}

\author{
Rajeswari Janarthanan, ${ }^{1}$ Alexey Serov,${ }^{2}$ Satyananda Kishore Pilli, ${ }^{1}$ Daniel A. Gamarra, ${ }^{1}$ \\ Plamen Atanassov, ${ }^{2}$ Michael R. Hibbs, ${ }^{3}$ and Andrew M. Herring. ${ }^{1,}$ * \\ ${ }^{1}$ Department of Chemical and Biological Engineering \\ Colorado School of Mines \\ Golden, CO 80401, USA \\ ${ }^{2}$ Department of Chemical and Biological Engineering \\ University of New Mexico \\ Albuquerque, NM 87131 \\ ${ }^{3}$ Sandia National Laboratories \\ P. O. Box 5800, MS 0888 \\ Albuquerque, NM 87185, USA
}

Submitted to Electrochimica Acta, ISPE-14 Special Issue

November $21^{\text {st }} 2014$

$1^{\text {st }}$ Revised Version

February $4^{\text {th }} 2015$

$2^{\text {nd }}$ Revised Version

March $26^{\text {th }} 2015$

* aherring@mines.edu 


\begin{abstract}
The objective of the current report is to compare the performance of poly(phenylene) based anion exchange membranes in an alkaline direct methanol fuel cell when platinum cathode catalysts are replaced with non-platinum cathode catalysts. In a $\mathrm{KOH}$-free methanol fuel, we show that a less expensive non-Pt cathode catalyst (derived from Fe-Aminoantipyrine, FeAAPyr, using Generations 1 and 2 sacrificial silica supports) provide better or comparable performance to commercial Pt cathode catalysts. The peak power density, current density and open circuit voltage of Fe-AAPyr-G-1 in $1 \mathrm{M}$ methanol at $80^{\circ} \mathrm{C}$ are $2.78 \mathrm{~mW} \mathrm{~cm}{ }^{-2}, 19.1 \mathrm{~mA} \mathrm{~cm}^{-}$ 2 and $0.7 \mathrm{~V}$ respectively. In a direct methanol fuel cell utilizing $\mathrm{KOH}$ in the fuel feed, the non-Pt catalyst shows promising peak power density of $52 \mathrm{~mW} \mathrm{~cm}{ }^{-2}$ with the Fe-AAPyr-G-2 cathode catalyst, comparable to a commercial Pt catalyst.
\end{abstract}

Keywords: Oxygen Reduction Reaction, Anion Exchange Membrane, Fuel Cell, Direct

Methanol Fuel Cell, non-Platinum Group Metal Catalyst 


\section{Introduction}

Alkaline fuel cells (AFCs) have the advantage over proton exchange membrane (PEM) fuel cells in that there is the possibility of using non-precious metal catalysts for both the oxygen reduction reaction and for fuel oxidation [1]. The recent advances in anion exchange membranes (AEMs) in terms of chemical durability and mechanical robustness has led to the development of fuel cells based on AEMs that have much higher system power densities than liquid electrolyte based AFCs [2-7]. Direct methanol AEM fuel cells (DMAEMFCs) have advantages over the equivalent PEM based fuel cells that include, simpler water management, lower methanol permeability, and the use of non- platinum metal catalysts [1,8]. All fuel cells run with this technology to date that show higher power densities use added $\mathrm{OH}^{-}$ions in the fuel. The ultimate aim would be to run these direct methanol fuel cells without added $\mathrm{KOH}$ [9]. The reason for adding hydroxide is that stoichiometrically the oxidation of methanol requires $6 \mathrm{OH}^{-}$ions, the hydroxide flushes the slow moving carbonate and bicarbonate, formed from reaction of $\mathrm{CO}_{2}$ and $\mathrm{OH}^{-}$, out of the anode and it improves the anode potential as $>300 \mathrm{mV}$ reduction in anode over potential is possible [5]. Comparison of DMAEMFCs with and without added $\mathrm{KOH}$ is useful as it sets a reference point with other reports and the chemical degradation of the MEA with added hydroxide especially at higher temperatures is much faster. The use of $\mathrm{KOH}$ has been reported with fuel cells using commercial AEMs such as the Tokuyama membrane, Fumatech FAA-2, and Morgane ADP by companies such as the Diahatsu Motor Company [10-16].

The most attractive feature of alkaline fuel cells is the use of non-Pt metal catalysts as they can operate with high stability and activity in alkaline media when compared to acidic media. In addition, this can also reduce the cost of fabricating fuel cell electrodes, $\mathrm{CO}$ poisoning, and the slow cathode reaction kinetics observed for platinum catalyst $[17,18]$. The methanol tolerance of non-Pt catalysts on the cathode would also reduce the voltage loss due to mixed potentials that is seen while methanol cross-over occurs to the cathode. The possible non-Pt cathode materials are reviewed in literature [19]. Non-Pt catalysts in alkaline fuel cells have been demonstrated to perform well with fuels such as hydrogen, methanol, and ethanol [20-27]. The motivation of alkaline direct methanol fuel cell (ADMFC) researchers is to develop non-Pt catalysts for both anode and cathode that in combination with AEMs exhibit high performance and long durability. 
Our previous work was focused on detailed study of two AEMs (ATMPP and TMAC6PP, both $2.4 \mathrm{meq} / \mathrm{g}$ ), developed by Sandia National Laboratories in an alkaline direct methanol fuel cell [9]. ATMPP and TMAC6PP are poly(phenylene) based AEMs with benzyltrimethylamonium (ATM) cation and trimethyl ammonium cation with a hexamethylene spacer (TMAC6) respectively (Figure 1). The ionomers TMAC6PPC61 and TMAC6PPC6h, Figure 1, using a hexamethylene chain introduced into the backbone to make the polymer more rubbery and soluble in organic solvents were developed in low and high IEC, $2.13 \mathrm{meq} \mathrm{g}^{-1}$ and $2.60 \mathrm{meq} \mathrm{g}^{-1}$ respectively. TMAC6PPC6h with a higher water uptake designed to increase the hydrophilicity of the anode thereby enhancing the diffusion of aqueous electrolyte and methanol; whereas the low water uptake TMAC6PPC61 was designed to reduce the flooding on the cathode [28]. Synthesis and properties of the ionomer such as water uptake and conductivity have been reported by one of the authors elsewhere [29-32]. The properties of these AEMs were demonstrated to be potential for fuel cell applications [29-31]. Furthermore, some of us, Atanassov et al. have demonstrated the application of the poly(phenylene) ionomer for electrocatalysis and $\mathrm{H}_{2}-\mathrm{O}_{2}$ fuel cells [33-35].

This paper is a logical extension of our previous work on application of these AEMs for DMAEMFCs with commercial platinum catalysts on both electrodes [9]. The study compared the performance of the AEMs with different catalysts and GDLs. As the details can be found elsewhere, here we summarize the results for the reader's better understanding. A comparison of the fuel cell performances in $\mathrm{KOH}$ free $1 \mathrm{M}$ methanol of the two AEMs, ATMPP and TMAC6PP with identical MEA components (both had a commercial $50 \% \mathrm{Pt}$ on high surface area carbon catalyst) showed a slightly better performance for the TMAC6PP MEA over ATMPP MEA. TMAC6PP MEA demonstrated peak power and current densities of $3.6 \mathrm{~mW} \mathrm{~cm}{ }^{-2}$ and $26.7 \mathrm{~mA}$ $\mathrm{cm}^{-2}$ while ATMPP MEA showed $3.1 \mathrm{~mW} \mathrm{~cm}^{-2}$ and $26.0 \mathrm{~mA} \mathrm{~cm}^{-2}$ at $80{ }^{\circ} \mathrm{C}, 100 \% \mathrm{RH}$. This slight improvement of TMAC6PP MEA could be related to the relatively better stability of TMAC6PP over ATMPP. This agrees with the results demonstrated by Hibbs that showed only $5 \%$ decrease in conductivity for TMAC6PP as opposed to $33 \%$ decrement for ATMPP after they were soaked in $4 \mathrm{M} \mathrm{KOH}$ for 14 days [29]. As the AEMs are new and the interfacial chemistries between catalysts have not been studied before, we investigated AEM-Catalyst combinations of the ATMPP with both commercial catalysts. The current densities of ATMPP-Etek and ATMPP50\% Pt/C MEAs were 7.2 and $26.0 \mathrm{~mA} \mathrm{~cm}^{-2}$ respectively. The power densities of ATMPP-Etek 
and ATMPP-50\%Pt/C MEAs were 3.1 and $0.85 \mathrm{~mW} \mathrm{~cm} \mathrm{~cm}^{-2}$ respectively. The key factors to enhance the performance was achieved by improving the hydrophilicity and hydrophobicity of the anode and cathode respectively. As we have compared the performances of AEMs in our previous work, the current report does not intend to compare these two AEMs.

The objective of the current report is to study the performance of alkaline direct methanol fuel cell using poly(phenylene) based anion exchange membranes when platinum cathode catalysts are replaced with non-platinum cathode catalysts prepared by some of the authors [36-40]. To achieve this, we studied TMAC6PP based MEAs with noble metal catalyst (commercial 50\%Pt/C, MEA-4) and non- noble metal catalyst, Fe-AAPyr-G2 (MEA-3). Similarly, ATMPP based MEAs were studied with and without noble metal cathode catalyst, MEA-2 and MEA-1 respectively. This now represents one of the first fuel cell investigations on non-platinum cathode catalysts reported, as most previous studies only report ORR activity in an aqueous halfcell $[41,42]$.

\section{Experimental}

\subsection{Materials}

The platinum catalysts, 20\% Pt on Vulcan XC-72 and $50 \% \mathrm{Pt}$ on high surface area carbon were purchased from E-TEK, Inc. and a commercial supplier respectively. Gas diffusion layers were a hydrophobic carbon cloth GDL, GDL LT 1400-W, from E-TEK, Inc. and a hydrophilic carbonized woven fiber fabric, Panex ${ }^{\circledR} 30$, from Zoltek. The AEMs, ATMPP and TMAC6PP, and ionomers, TMAC6PPC61 and TMAC6PPC6h, were prepared as reported previously [29, 30]. Fe-AAPyr catalysts were prepared by wet impregnation of iron and aminoantipyrine precursors (Sigma Aldrich) onto the surface of two different silicas, Generation-1: Cab-O-Sil ${ }^{\mathrm{TM}}$ EH-5, surface area: $\sim 400 \mathrm{~m}^{2} \mathrm{~g}^{-1}$ and Generation-2: Cab-O-Sil ${ }^{\mathrm{TM}} \mathrm{M}-5$, surface area: $225 \mathrm{~m}^{2} \mathrm{~g}^{-1}$, designated Fe-AAPyr-G1 and Fe-AAPyr-G2 respectively. First, a calculated amount of silica (the total metal loading on silica was calculated as $~ 20 \mathrm{wt} . \%$ ) was dispersed in a mixture of water and acetone (1:1 by volume) in an ultrasound bath. Then, a solution of aminoantipyrine in acetone was added to silica and ultrasonicated for $40 \mathrm{~min}$. Finally, a solution of iron nitrate $\left(\mathrm{Fe}\left(\mathrm{NO}_{3}\right)_{3} .9 \mathrm{H}_{2} \mathrm{O}\right)$ was added to $\mathrm{SiO}_{2}-\mathrm{AAPyr}$ solution and ultrasonicated for $8 \mathrm{~h}$. After ultrasonic treatment viscous gel of silica and Fe-AAPyr was dried overnight at $\mathrm{T}=85^{\circ} \mathrm{C}$. The obtained solid 
was ground to a fine powder, and then subjected heat treatment (HT). The general conditions of HT were UHP nitrogen (flow rate $100 \mathrm{cc} \mathrm{min}^{-1}$ ), $10 \mathrm{deg} \mathrm{min}^{-1}$ temperature ramp rate, and a $1 \mathrm{~h}$ pyrolyzation time at $\mathrm{T}=900{ }^{\circ} \mathrm{C}$. The sacrificial support was removed by means of 20 wt. $\%$ of HF. The obtained wet powder was washed by DI water until $\mathrm{pH} \sim 5$ and dried at $\mathrm{T}=45^{\circ} \mathrm{C}$.

\subsection{Characterization}

The catalysts were characterized by Brunauer-Emmet-Teller (BET) measurements, SEM (Hitachi S-5200) and TEM (JEOL 2010 EX HREM).

\subsection{Ring Disk Electrode}

Electrochemical analysis for synthesized catalysts was performed using the Pine Instrument Company electrochemical analysis system. The rotational speed was 1200RPM, with a scan rate of $5 \mathrm{mV} \mathrm{sec}{ }^{-1}$. The electrolyte was $1 \mathrm{M} \mathrm{KOH}$ saturated in $\mathrm{O}_{2}$ at room temperature. A platinum wire counter electrode, and $\mathrm{Hg} / \mathrm{HgO}$ were used.

Working electrodes were prepared by mixing $5 \mathrm{mg}$ of the Fe-AAPyr electrocatalyst with $850 \mu \mathrm{L}$ of isopropyl alcohol, and $150 \mu \mathrm{L}$ of $\mathrm{Nafion}^{\circledR}$ (0.5\% wt., DuPont). The mixture was sonicated before $30 \mu \mathrm{L}$ was applied onto a glassy carbon disk with a sectional area of $0.2474 \mathrm{~cm}^{2}$. The loading of catalyst on the electrode was $0.6 \mathrm{mg} \mathrm{cm}$.

\subsection{Membrane Electrode Assembly (MEA)}

Table 1 details the components of MEAs studied in this paper. MEAs were fabricated with commercial $20 \% \mathrm{Pt} / \mathrm{C}$, E-TEK (MEA-1 and MEA-2) and $50 \% \mathrm{Pt} / \mathrm{C}$ (MEA-3 and 4) as anode catalysts. Fe-AAPyr-G-1 and Fe-AAPyr-G-2 are the cathode catalysts used in MEA-1 and MEA3. To compare the performance of non-Pt cathode catalysts (MEA-1 and MEA-3), control MEAs (MEA-2 and MEA-4) were fabricated with the two commercial catalysts. In general, catalyst inks were made by mixing catalyst, DI water, isopropanol and ATMPP or TMAC6PPC61 (IEC: $2.13 \mathrm{meq} / \mathrm{g}$ ) and TMAC6PPC6h (IEC: $2.60 \mathrm{meq} / \mathrm{g}$ ) (3\% solution in methanol) with a catalyst to ionomer mass ratio of $4: 1$. Catalyst inks were painted on $5.48 \mathrm{~cm}^{2}$ gas diffusion layers to obtain a loading of $1.4 \mathrm{mg}$ of $\mathrm{Pt} \mathrm{cm} \mathrm{cm}^{-2}$ with an ETEK catalyst, $2.5 \mathrm{mg}$ of $\mathrm{Pt} \mathrm{cm}^{-2}$ with the commercial catalyst and $5.48 \mathrm{mg} \mathrm{cm}^{-2}$ of Fe-AAPyr-G-1 and Fe-AAPyr-G-2 catalyst. The electrodes were hot pressed on ATMPP or TMAC6PP membranes using a digital combo multi- purpose press, 
DC14, Geo Knight \& Co. Inc. at $66{ }^{\circ} \mathrm{C}$ and 80 psig for 90s. Prior to any tests, MEAs were soaked in $1 \mathrm{M} \mathrm{NaOH}$ for $2 \mathrm{~h}$ to convert the membrane from the $\mathrm{Br}^{-}$form to $\mathrm{OH}^{-}$form. Following this, MEAs were subsequently soaked in water with frequent changes of water to ensure complete removal of $\mathrm{NaOH}$ and to obtain a neutral $\mathrm{pH}$.

\subsection{Fuel Cell Testing}

Single cell hardware from Fuel Cell technologies, Inc. with a working area of $5.48 \mathrm{~cm}^{2}$ and single serpentine flow fields was used. The supplied anodized aluminum endplates were replaced with stainless steel end plates to withstand the alkaline conditions. The effluent from the fuel cell reaches the back-pressure regulators, followed by a water trap which separates out any condensed liquid in the exit lines. An isocratic HPLC pump (Chromtech) was used to pump the methanol solution or methanol in $\mathrm{KOH}$ solution to the anode. Oxygen was fed to the cathode through a modular gas handling/gas metering system (Lynntech Industry, Inc.) through a humidity bottle maintained at $80{ }^{\circ} \mathrm{C}$. The purge gas $\mathrm{N}_{2}$ and flow rate of $\mathrm{O}_{2}$ was controlled using FC power software (Lynntech Industry, Inc.). The fuel and oxygen flow rates were set to $0.5 \mathrm{ml}$ $\mathrm{min}^{-1}$ and $0.2 \mathrm{~L} \mathrm{~min}^{-1}$ respectively in this study. The cell temperature was controlled at $80{ }^{\circ} \mathrm{C}$.

A MSTAT4+ multi-potentiostat (Arbin Instruments) was used to conduct polarization experiments. The polarization curves were obtained by stepping down the potential from open circuit potential until the limiting current is achieved. In situ impedance spectra were measured potentiostatically at different potentials on the polarization curve using a Gamry Instruments potentiostat. The frequencies were varied between 100,000 and $0.1 \mathrm{~Hz}$ with the data points being 10 per decade. The AC voltage was $10 \mathrm{mV}$ root mean squared.

\section{Results and Discussion}

\subsection{Catalyst Characterization}

The catalysts were prepared via the sacrificial support method (SSM) [36-40].The morphology of the catalysts is shown in Figure 2. It can be seen in the SEM and TEM images of Fe-AAPyrG1 materials that the catalyst consists of a well-developed porous matrix (Figure $2 \mathrm{a}, \mathrm{b}$ ). The analysis of the SEM and TEM images revealed that material has at least bi-modal pore size distribution: smaller pores in the range of $20-40 \mathrm{~nm}$ and larger pores with diameter $>100 \mathrm{~nm}$. Based on the empirical observation from our previous works smaller pores can be related to 
decomposition of organic precursor while larger pores are formed after silica support removal. The ratio between silica and organic precursor as well as a nature of sacrificial support allows the controlling final morphology of catalysts. It should be mentioned that due to the fact that these catalysts are fabricated by the sacrificial support method that does not utilize artificially added carbon (in contrast to conventional methods) the density of active sites in open-frame structure is significantly higher compared with traditional catalysts[39]. The surface area of both materials is $650 \mathrm{~m}^{2} / \mathrm{g}$. It is well-known fact that presence of $\mathrm{Fe}^{2+} / \mathrm{Fe}^{3+}$ pairs can result in formation of radical and fast degradation of anion-exchange membrane. The TEM images were collected in multiple spots of catalysts in order to determine the presence of residual iron nano-particles. Such nanoparticles were not observed which can be expected taking into account aggressive leaching step with HF acid.

In order to evaluate influence of heat treatment parameters of the catalysts, such as temperature and duration of the pyrolysis, we prepared 4 different catalysts. Those materials were screened in Rotating Disk Electrode experiment in $1 \mathrm{M} \mathrm{KOH}$, saturated with $\mathrm{O}_{2}$, Figure 3. The results are compared to the commercial Pt catalyst and as can be seen in the Figure the Fe containing catalysts all outperform the Pt containing catalyst in base. It was found that Fe-AAPyr-G1 synthesized at $\mathrm{T}=900{ }^{\circ} \mathrm{C}$ and $\mathrm{t}=1 \mathrm{~h}$ had the highest activity and so this material was downselected for further MEA tests in the fuel cell.

\subsection{Direct Methanol Fuel cell without $\mathrm{KOH}$}

Here we compare the data for the Fe containing cathode electrodes to the Pt baselining studies of our previous report [9]. The data for all of the MEAs is shown in Figure 4 at $80{ }^{\circ} \mathrm{C}, 100 \% \mathrm{RH}$ using $1 \mathrm{M}$ methanol. The fuel cell performances of both the non-Pt cathode catalysts (Fe-AAPyrG1 and Fe-AAPyr-G2) are compared to commercial Pt cathode catalysts from Etek (20\% Pt/C) and the other commercial supplier $(50 \% \mathrm{Pt} / \mathrm{C})$. We were able to operate the fuel cell at $80{ }^{\circ} \mathrm{C}$ and collect steady state data as these membranes have good chemical stability. AEM Fuel cells are usually operated at $60{ }^{\circ} \mathrm{C}$ as many cationic ammonium groups decompose above this temperature under fuel cell operation. The elevated temperature enables carbonate decomposition in the anode, improves the electrode kinetics, and reduces the thermodynamic voltage losses $[6,25]$. It can be seen Fe-AAPyr-G1 cathode (MEA-1) outperformed the commercial cathode (MEA-2) in terms of open circuit voltage (OCV), power and current densities (Table 2). MEA-1 (0.7 V) 
shows $240 \mathrm{mV}$ higher OCV than the MEA-2 $(0.46 \mathrm{~V})$, indicating less of the methanol that crossed over the membrane reacted with the non-Pt cathode catalyst. The maximum current densities of MEA-1 and 2 were 19.1 and $7.2 \mathrm{~mA} \mathrm{~cm}^{-2}$; the peak power densities being 2.78 and 0.85 for MEA-1 and 2 respectively. The normalized current density at $0.1 \mathrm{~V}$ was comparable on a mass basis for both catalysts, which is significant considering the very high market price of Pt as compared to Fe. All other components of the MEAs being identical, the enhanced performance of MEA-1 can be attributed to the Fe-N-C catalyst.

Polarization curves measured for Fe-AAPyr-G2 cathode (MEA-3) and its control MEA-4 with the commercial Pt cathode catalyst demonstrated $120 \mathrm{mV}$ higher OCV for the Fe-AAPyrG2catalyst indicating better methanol tolerance (Figure 4). These systems use the more chemically stable TMAC6PP membrane, derivative ionomers, the comercial Pt catalyst and Zoltek hydrophilic GDL in the anode. Nevertheless, the commercial Pt catalyst achieved higher current and power densities than the non-Pt catalyst. At low current density region, until 1.35 $\mathrm{mA} \mathrm{cm}{ }^{-2}$, there is not much difference in their performances, implying the same kinetic losses of the catalyst systems in the electrode. When a higher current is drawn from the cell, MEA-3 showed an increased ohmic drop, voltage dropped rapidly to reach a maximum current density of $9.8 \mathrm{~mA} \mathrm{~cm}^{-2}$. MEA-4 showed a lesser ohmic loss, a steady drop in the voltage upon high current draw was observed to reach a maximum current density of $29.5 \mathrm{~mA} \mathrm{~cm}{ }^{-2}$, which is three times higher than for the non-Pt catalyst. This implies that the long chain TMAC6PP61 ionomer interacts less well in terms of ionic conductivity with the Fe-AAPyr-G2 catalyst than it does with the Pt catalyst. The poor compatibility of Fe-AAPyr-TMAC6PPC61 interface could have been due to a relatively higher degree of swelling and de-swelling of the ionomer resulting in a poor performance. To ensure this, in depth investigations of the transport properties of TMAC6PPC61 are required. The poor catalyst binder interaction is also evident from a rapid voltage drop with significant ohmic loss. To elucidate the ohmic loss difference between the two MEAs, impedance spectra of the MEAs were measured during fuel cell operation at $400 \mathrm{mV}$ (Figure 5). Ohmic resistance which is the high frequency intercept (x-axis intercept), were $50 \mathrm{~m} \Omega \mathrm{cm}^{-2}$ and $27 \mathrm{~m} \Omega \mathrm{cm}^{-2}$ for MEA-3 and MEA-4 respectively [20, 25, 43]. Ohmic resistance has resulted from the cathode catalyst and its interaction with the ionomer as all other components of the MEAs remain the same. The power density achieved by the MEA-4 $\left(3.97 \mathrm{~mW} \mathrm{~cm}^{-2}\right)$ is 2.8 times higher than the MEA-3 $\left(1.40 \mathrm{~mW} \mathrm{~cm}^{-2}\right)$. The maximum power density achieved for the $\mathrm{Fe}$ - 
AAPyr-G2 cathode catalyst MEA is only half that of the Pt cathode MEA, which is significant when one considers the raw materials costs.

\subsection{Direct Methanol fuel cell with added $\mathrm{KOH}$}

In the presence of $\mathrm{KOH}$, ATMPP Fe-AAPyr-G1 based MEAs-1 and its Pt-control MEA-2 demonstrated enhanced performance (Figure 6). As shown in the literature, the enhancement could be due to adequate supply of $\mathrm{OH}^{-}$ions required for methanol oxidation and reduced anode over potential [44]. The performance of MEA-1 was superior both in the presence and absence of $\mathrm{KOH}$ when compared to MEA-2, but still lower than the systems with the TMAC6PP membrane, the commercial Pt catalyst and Zoltek anode GDL. MEA-2 had a $0.93 \mathrm{~V} \mathrm{OCV}$, which is $100 \mathrm{mV}$ higher than the MEA-1 $(0.83 \mathrm{~V})$. The low current slope of MEA-1s polarization curve is also much steeper than for the Pt cathode, implying that the non-precious catalyst does not do as well kinetically. Significant ohmic loss was observed in the Pt-catalyzed cathode, MEA-2, and the voltage dropped rapidly from the OCV when high current was drawn from the cell and was inoperable below, $0.35 \mathrm{~V}$, suggesting significant issues with the ATMPP ionomer and $\mathrm{Pt}$ catalyst. In comparison to the control, the non-Pt catalyst performed much better in terms of ohmic losses, the voltage drop was steady when a higher current was drawn. A maximum current density of $117 \mathrm{~mA} \mathrm{~cm}^{-2}$ was achieved which is 2.3 times higher than MEA-2 which reached a maximum of $50.7 \mathrm{~mA} \mathrm{~cm}^{-2}$. The corresponding peak power densities of MEA-1 and MEA-2 were 17.7 and $24.7 \mathrm{~mW} \mathrm{~cm}^{-2}$ respectively.

In our previous study using Pt on both sides of the MEA, we showed that the best performance was with the commercial Pt catalyst, the long chain cationic membrane, TMAC6PP with TMAC6PPC6 ionomers, and the Zoltek hydrophilic GDL on the anode [9]. We also demonstrated the effect of varying $\mathrm{MeOH}$ and $\mathrm{KOH}$ concentration. In the presence of $\mathrm{KOH}$, MEA-3 also showed significant improvement in the performance and the comparable data is shown in, Figure 7. The open circuit potentials at all concentrations were very close, $\sim 0.88 \mathrm{~V}$ (Table 3) [21]. This fact shows that the Fe based catalyst shows excellent tolerance towards $\mathrm{MeOH}$ oxidation as the $\mathrm{OCV}$ is invariant with $\mathrm{MeOH}$ concentration, and if it reacted with the $\mathrm{MeOH}$ would fall with increasing $\mathrm{MeOH}$ concentration. The maximum current density and peak power density for the baseline, $1 \mathrm{M}$ methanol and $1 \mathrm{M} \mathrm{KOH}$ were $167.78 \mathrm{~mA} \mathrm{~cm}^{-2}$ and $44.2 \mathrm{~mW}$ $\mathrm{cm}^{-2}$ respectively. When either the electrolyte or $\mathrm{KOH}$ concentration was increased to $2 \mathrm{M}$, the 
performances were found to improve when compared to the baseline $1 \mathrm{M}-1 \mathrm{M}$ concentrations, the maximum current density and peak power density increased up to $182.5 \mathrm{~mA} \mathrm{~cm}^{-2}$ and $47.6 \mathrm{~mW}$ $\mathrm{cm}^{-2}$ respectively for $1 \mathrm{M}-2 \mathrm{M}$ concentration and these values were $217.9 \mathrm{~mA} \mathrm{~cm}$ and $47.5 \mathrm{~mW}$ $\mathrm{cm}^{-2}$ for $2 \mathrm{M}-1 \mathrm{M}$ concentration. When both fuel and electrolyte concentrations were increased to $2 \mathrm{M}$, the best performance was observed, with a maximum current density of $234.35 \mathrm{~mA} \mathrm{~cm}$ and $51.97 \mathrm{~mW} \mathrm{~cm}^{-2}$ respectively. A further raise of fuel and $\mathrm{KOH}$ concentration to $3 \mathrm{M}$, reduced the current density and power density to $229 \mathrm{~mA} \mathrm{~cm}^{-2}$ and $45.9 \mathrm{~mW} \mathrm{~cm}^{-2}$ respectively. The Pt cathode catalyst system showed the best performance at $1 \mathrm{M} \mathrm{MeOH}$ and $1 \mathrm{M} \mathrm{KOH}, 226 \mathrm{~mA} \mathrm{~cm}^{-2}$ current density and $53.4 \mathrm{~mW} \mathrm{~cm}^{-2}$ power density [9]. So in $\mathrm{KOH}$ the non-precious Fe-AAPyrG2 catalyst has the same performance as the Pt-catalyst on the cathode, demonstrating that nonprecious catalyst are indeed practical in AEM fuel cells and also offer the possibility of $\mathrm{MeOH}$ tolerance, negating the effects of $\mathrm{MeOH}$ crossover through the membrane.

The performance comparison between Figures 3 and 4 demonstrate that the replacement of nonPt cathode catalyst did not compromise the performance. This performance of the non-Pt catalyst is better than the power density observed from many MEAs with commercial AEMs and Pt catalysts in the presence of $\mathrm{KOH}$. With a Morgane ADP from Solvay and Pt catalysts, power densities between 6 and $10 \mathrm{~mW} \mathrm{~cm}^{2}$ are reported [12]. Similarly, with a Tokuyama membrane and a Pt catalysts a peak power density of $12.8 \mathrm{~mW} \mathrm{~cm}^{-2}$ was observed in $7 \mathrm{M}$ methanol and $1 \mathrm{M}$ $\mathrm{KOH}[14]$.

\section{Conclusions}

This work reports the study of non-platinum cathode catalysts with poly(phenylene) based AEMs, ATMPP and TMAC6PP for direct methanol alkaline fuel cells. In the absence of $\mathrm{KOH}$ both the Fe-AAPyr-G1 and Fe-AAPyr-G2 catalysts gave much higher OCVs when used as the catalyst I the cathode than $\mathrm{Pt}$, due to their superior ability to resist $\mathrm{MeOH}$ oxidation. The FeAAPyr-G1 cathode catalyst with ATMPP membrane outperformed the platinum catalyst (Etek) in $\mathrm{KOH}$ free methanol showing remarkably three times enhancement in power density. The enhanced performance of Fe-AAPyr-G-1 in terms of OCV, power and current densities was attributed to the non-platinum cathode catalyst. Nevertheless, the performance of Fe-AAPyr-G-2 was not as significant ( 2.8 times low power density) and was lower than the commercial Pt catalyst with a TMAC6PP. This is attributed to the poorer compatibility of the TMAC6PPC6 
ionomer with the Fe based catalyst. Nevertheless, both catalysts performance is significant when precious metal material costs are factored.

The OCV advantage of the Fe based catalysts versus the Pt based catalysts was not as significant when the $\mathrm{MeOH}$ fuel was co-fed with $\mathrm{KOH}$. Investigation of the activities in $\mathrm{KOH}$ demonstrated better performance for Fe-AAPyr-G1 when compared to the Etek Pt catalyst in the ATMPP system, showing 1.4 times higher power density. When using the Fe-AAPyr-G2 and the commercial Pt catalyst in $\mathrm{KOH}$ in the TMAC6PPC6 system the same high current densities could be achieved for both Fe based and Pt based catalysts, although the optimum performance for the Fe based system was at $2 \mathrm{M}$ concentration for both $\mathrm{MeOH}$ and $\mathrm{KOH}$. This study shows that the Fe-AAPyr catalyst can replace Pt catalysts in the cathode of direct $\mathrm{MeOH}$ fuel cells using AEMs and that these catalysts may be tuned to have even superior performance.

\section{Acknowledgments}

This work was supported by the Laboratory Directed Research and Development (LDRD) program at Sandia National Laboratories. Sandia National Laboratory is a multi-program laboratory operated by Sandia Corporation, a wholly owned subsidiary of Lockheed Martin

Company, for the U. S. Department of Energy's National Nuclear Security Administration under contract DE-AC04-94AL85000.

\section{References}

[1] J.S. Spendelow, A. Wieckowski, Phys. Chem. Chem. Phys., 9 (2007) 2654-2875.

[2] M.A. Hickner, A.M. Herring, E.B. Coughlin, Anion exchange membranes: Current status and moving forward, Journal of Polymer Science Part B: Polymer Physics, 51 (2013) 1727-1735.

[3] M.A. Hickner, Ion-containing polymers: new energy \&amp; clean water, Materials Today, 13 (2010) 34-41.

[4] E.H. Yu, U. Krewer, K. Scott, Principles and Materials Aspects of Direct Alkaline Alcohol Fuel Cells, Energies, 3 (2010) 1499-1528. 
[5] J.R. Varcoe, P. Atanassov, D.R. Dekel, A.M. Herring, M.A. Hickner, P.A. Kohl, A.R. Kucernak, W.E. Mustain, K. Nijmeijer, K. Scott, T. Xu, L. Zhuang, Anion-exchange membranes in electrochemical energy systems, Energy Environ. Sci., 7 (2014) 3135-3191.

[6] J.R. Varcoe, R.C.T. Slade, Prospects for Alkaline Anion-Exchange Membranes in Low Temperature Fuel Cells, Fuel Cells, 5 (2005) 187-200.

[7] J.R. Varcoe, R.C.T. Slade, E. Lam How Yee, An alkaline polymer electrochemical interface: a breakthrough in application of alkaline anion-exchange membranes in fuel cells, Chemical Communications, (2006) 1428-1429.

[8] E. Antolini, E.R. Gonzalez, Alkaline direct alcohol fuel cells, Journal of Power Sources, 195 (2010) 3431-3450.

[9] R. Janarthanan, S. Kishore Pilli, J.L. Horan, D.A. Gamarra, M.R. Hibbs, A.M. Herring, A Direct Methanol Alkaline Fuel Cell Based on Poly(phenylene) Anion Exchange Membranes, Journal of The Electrochemical Society, 161 (2014) F944-F950.

[10] K. Asazawa, T. Sakamoto, S. Yamaguchi, K. Yamada, H. Fujikawa, H. Tanaka, K. Oguro, Study of Anode Catalysts and Fuel Concentration on Direct Hydrazine Alkaline AnionExchange Membrane Fuel Cells, Journal of The Electrochemical Society, 156 (2009) B509B512.

[11] T. Sakamoto, K. Asazawa, K. Yamada, H. Tanaka, Study of Pt-free anode catalysts for anion exchange membrane fuel cells, Catalysis Today, 164 (2011) 181-185.

[12] E.H. Yu, K. Scott, Development of direct methanol alkaline fuel cells using anion exchange membranes, Journal of Power Sources, 137 (2004) 248-256. 
[13] A. Santasalo-Aarnio, S. Hietala, T. Rauhala, T. Kallio, In and ex situ characterization of an anion-exchange membrane for alkaline direct methanol fuel cell (ADMFC), Journal of Power Sources, 196 (2011) 6153-6159.

[14] J.-H. Kim, H.-K. Kim, K.-T. Hwang, J.-Y. Lee, Performance of air-breathing direct methanol fuel cell with anion-exchange membrane, International Journal of Hydrogen Energy, $35(2010)$ 768-773.

[15] G.K.S. Prakash, F.C. Krause, F.A. Viva, S.R. Narayanan, G.A. Olah, Study of operating conditions and cell design on the performance of alkaline anion exchange membrane based direct methanol fuel cells, Journal of Power Sources, 196 (2011) 7967-7972.

[16] J. Kim, T. Momma, T. Osaka, Cell performance of Pd-Sn catalyst in passive direct methanol alkaline fuel cell using anion exchange membrane, Journal of Power Sources, 189 (2009) 999-1002.

[17] E.H. Yu, X. Wang, U. Krewer, L. Li, K. Scott, Direct oxidation alkaline fuel cells: from materials to systems, Energy \& Environmental Science, 5 (2012) 5668-5680.

[18] Y.-J. Wang, J. Qiao, R. Baker, J. Zhang, Alkaline polymer electrolyte membranes for fuel cell applications, Chemical Society Reviews, 42 (2013) 5768-5787.

[19] N.A. Karim, S.K. Kamarudin, An overview on non-platinum cathode catalysts for direct methanol fuel cell, Applied Energy, 103 (2013) 212-220.

[20] Z. Wang, L. Xin, X. Zhao, Y. Qiu, Z. Zhang, O.A. Baturina, W. Li, Carbon supported Ag nanoparticles with different particle size as cathode catalysts for anion exchange membrane direct glycerol fuel cells, Renewable Energy, 62 (2014) 556-562.

[21] H. Bunazawa, Y. Yamazaki, Ultrasonic synthesis and evaluation of non-platinum catalysts for alkaline direct methanol fuel cells, Journal of Power Sources, 190 (2009) 210-215. 
[22] X. Li, B.N. Popov, T. Kawahara, H. Yanagi, Non-precious metal catalysts synthesized from precursors of carbon, nitrogen, and transition metal for oxygen reduction in alkaline fuel cells, Journal of Power Sources, 196 (2011) 1717-1722.

[23] M. Mamlouk, S.M.S. Kumar, P. Gouerec, K. Scott, Electrochemical and fuel cell evaluation of Co based catalyst for oxygen reduction in anion exchange polymer membrane fuel cells, Journal of Power Sources, 196 (2011) 7594-7600.

[24] M. Piana, M. Boccia, A. Filpi, E. Flammia, H.A. Miller, M. Orsini, F. Salusti, S. Santiccioli, F. Ciardelli, A. Pucci, H2/air alkaline membrane fuel cell performance and durability, using novel ionomer and non-platinum group metal cathode catalyst, Journal of Power Sources, 195 (2010) 5875-5881.

[25] T. Hibino, K. Kobayashi, Hydroxide ion conduction in molybdenum(vi)-doped tin pyrophosphate at intermediate temperatures, Journal of Materials Chemistry A, 1 (2013) 69346941.

[26] Q. Hu, G. Li, J. Pan, L. Tan, J. Lu, L. Zhuang, Alkaline polymer electrolyte fuel cell with Ni-based anode and Co-based cathode, International Journal of Hydrogen Energy, 38 (2013) $16264-16268$.

[27] F. Bidault, A. Kucernak, Cathode development for alkaline fuel cells based on a porous silver membrane, Journal of Power Sources, 196 (2011) 4950-4956.

[28] H. Kim, J. Zhou, M. Ünlü, I. Anestis-Richard, K. Joseph, P.A. Kohl, The effect of hydrophobicity in alkaline electrodes for passive DMFC, Electrochimica Acta, 56 (2011) 30853090.

[29] M.R. Hibbs, Alkaline stability of poly(phenylene)-based anion exchange membranes with various cations, Journal of Polymer Science Part B: Polymer Physics, 51 (2013) 1736-1742. 
[30] M.R. Hibbs, C.H. Fujimoto, C.J. Cornelius, Synthesis and Characterization of Poly(phenylene)-Based Anion Exchange Membranes for Alkaline Fuel Cells, Macromolecules, 42 (2009) 8316-8321.

[31] R. Janarthanan, J.L. Horan, B.R. Caire, Z.C. Ziegler, Y. Yang, X. Zuo, M.W. Liberatore, M.R. Hibbs, A.M. Herring, Understanding anion transport in an aminated trimethyl polyphenylene with high anionic conductivity, Journal of Polymer Science Part B: Polymer Physics, 51 (2013) 1743-1750.

[32] T.M. Alam, M.R. Hibbs, Characterization of Heterogeneous Solvent Diffusion Environments in Anion Exchange Membranes, Macromolecules, 47 (2014) 1073-1084.

[33] M. Robson, K. Artyushkova, W. Patterson, P. Atanassov, M. Hibbs, Non-platinum CarbonSupported Oxygen Reduction Catalyst Ink Evaluation Based on Poly(sulfone) and Poly(phenylene)-Derived Ionomers in Alkaline Media, Electrocatalysis, 5 (2014) 148-158.

[34] E.E. Switzer, T.S. Olson, A.K. Datye, P. Atanassov, M.R. Hibbs, C.J. Cornelius, Templated $\mathrm{Pt}-\mathrm{Sn}$ electrocatalysts for ethanol, methanol and $\mathrm{CO}$ oxidation in alkaline media, Electrochimica Acta, 54 (2009) 989-995.

[35] E.E. Switzer, T.S. Olson, A.K. Datye, P. Atanassov, M.R. Hibbs, C. Fujimoto, C.J. Cornelius, Novel KOH-free anion-exchange membrane fuel cell: Performance comparison of alternative anion-exchange ionomers in catalyst ink, Electrochimica Acta, 55 (2010) 3404-3408. [36] N.I. Andersen, A. Serov, P. Atanassov, Metal oxides/CNT nano-composite catalysts for oxygen reduction/oxygen evolution in alkaline media, Applied Catalysis B: Environmental, 163 (2015) 623-627. 
[37] A. Serov, K. Artyushkova, P. Atanassov, Fe-N-C Oxygen Reduction Fuel Cell Catalyst Derived from Carbendazim: Synthesis, Structure, and Reactivity, Advanced Energy Materials, 4 (2014) n/a-n/a.

[38] A. Serov, A. Aziznia, P.H. Benhangi, K. Artyushkova, P. Atanassov, E. Gyenge, Borohydride-tolerant oxygen electroreduction catalyst for mixed-reactant Swiss-roll direct borohydride fuel cells, Journal of Materials Chemistry A, 1 (2013) 14384-14391.

[39] A. Serov, U. Tylus, K. Artyushkova, S. Mukerjee, P. Atanassov, Mechanistic studies of oxygen reduction on Fe-PEI derived non-PGM electrocatalysts, Applied Catalysis B: Environmental, 150-151 (2014) 179-186.

[40] U. Tylus, Q. Jia, K. Strickland, N. Ramaswamy, A. Serov, P. Atanassov, S. Mukerjee, Elucidating Oxygen Reduction Active Sites in Pyrolyzed Metal-Nitrogen Coordinated NonPrecious-Metal Electrocatalyst Systems, The Journal of Physical Chemistry C, 118 (2014) 89999008.

[41] P. Manivasakan, P. Ramasamy, J. Kim, Use of urchin-like NixCo3-xO4 hierarchical nanostructures based on non-precious metals as bifunctional electrocatalysts for anion-exchange membrane alkaline alcohol fuel cells, Nanoscale, 6 (2014) 9665-9672.

[42] A. Serov, M.H. Robson, K. Artyushkova, P. Atanassov, Templated non-PGM cathode catalysts derived from iron and poly(ethyleneimine) precursors, Applied Catalysis B: Environmental, 127 (2012) 300-306.

[43] C. Tamain, S.D. Poynton, R.C.T. Slade, B. Carroll, J.R. Varcoe, Development of Cathode Architectures Customized for H2/O2 Metal-Cation-Free Alkaline Membrane Fuel Cells, The Journal of Physical Chemistry C, 111 (2007) 18423-18430. 
[44] J.R. Varcoe, P. Atanassov, D.R. Dekel, A.M. Herring, M.A. Hickner, P.A. Kohl, A.R. Kucernak, W.E. Mustain, K. Nijmeijer, K. Scott, T. Xu, L. Zhuang, Anion-exchange membranes in electrochemical energy systems, Energy \& Environmental Science, 7 (2014) 3135-3191.

Table 1. Membrane Electrode Assemblies and their components

\begin{tabular}{|l|l|l|l|l|l|l|l|}
\hline MEA & $\begin{array}{l}\text { Anode } \\
\text { Catalyst }\end{array}$ & $\begin{array}{l}\text { Anode } \\
\text { GDL }\end{array}$ & Anode Ionomer & Cathode & $\begin{array}{l}\text { Cathode } \\
\text { GDL }\end{array}$ & $\begin{array}{l}\text { Cathode } \\
\text { Ionomer }\end{array}$ & AEM \\
\hline MEA-1 & $\begin{array}{l}\text { Pt/C, } \\
\text { Etek }\end{array}$ & Etek & ATMPP & Fe-AAPyr-G1 & Etek & ATMPP & ATMPP \\
\hline $\begin{array}{l}\text { MEA-2 } \\
{[9]}\end{array}$ & $\begin{array}{l}\text { Pt/C, } \\
\text { Etek }\end{array}$ & Etek & ATMPP & Pt/C, Etek & Etek & ATMPP & ATMPP \\
\hline MEA-3 & $\begin{array}{l}\text { Pt/C, } \\
50 \% P t / C\end{array}$ & Ztek & TMAC6PPC6h & $\begin{array}{l}\text { Fe-AAPyr- } \\
\text { G2 }\end{array}$ & Etek & TMAC6PPC61 & TMAC6PP \\
\hline $\begin{array}{l}\text { MEA-4 } \\
{[9]}\end{array}$ & $\begin{array}{l}\text { Pt/C, } \\
50 \% P t / C\end{array}$ & Ztek & TMAC6PPC6h & $\begin{array}{l}\text { Pt/C, } \\
50 \% P t / C\end{array}$ & Etek & TMAC6PPC61 & TMAC6PP \\
\hline
\end{tabular}


Table 2. Fuel cell performance data in $1 \mathrm{M}$ Methanol at $80{ }^{\circ} \mathrm{C}, 100 \% \mathrm{RH}$

\begin{tabular}{|l|l|l|l|l|}
\hline MEA & OCP $(\mathrm{V})$ & $\begin{array}{l}\text { Current density at } \\
0.1 \mathrm{~V} \\
(\mathrm{~mA} \mathrm{~cm})^{-2}\end{array}$ & $\begin{array}{l}\text { Current density at 0.1 } \\
\mathrm{V}\left(\mathrm{mA} \mathrm{cm}^{-2} \mathrm{mgP}^{-1} \text { or }\right. \\
\left.\mathrm{mg}(\mathrm{Fe}-\mathrm{N}-\mathrm{C})^{-1}\right)^{* *}\end{array}$ & $\begin{array}{l}\text { Peak Power } \\
\text { density } \\
\left(\mathrm{mW} \mathrm{cm}^{-2}\right)\end{array}$ \\
\hline MEA-1 & 0.7 & $19.1($ at $0.15 \mathrm{~V})$ & $3.48^{* *}$ & 2.78 \\
\hline MEA-2 [9] & 0.46 & 7.2 & 5.14 & 0.85 \\
\hline MEA-3 & 0.68 & 9.8 & $1.78^{* *}$ & 1.40 \\
\hline MEA-4 [9] & 0.56 & 29.5 & 11.5 & 3.97 \\
\hline
\end{tabular}


Table 3. DMAFC results as a function of concentrations of methanol and $\mathrm{KOH}$ at $80{ }^{\circ} \mathrm{C}, 100 \%$ RH

\begin{tabular}{lllllll} 
MeOH - KOH & MEA-3 & \multicolumn{5}{c}{ MEA-4 [9] } \\
& $\begin{array}{l}\text { OCP } \\
(\mathrm{V})\end{array}$ & $\begin{array}{l}\text { Current } \\
\text { density } \\
\left.(\mathrm{mA} \mathrm{cm})^{-2}\right)\end{array}$ & $\begin{array}{l}\text { Peak Power } \\
\text { Density } \\
\left(\mathrm{mW} \mathrm{cm} \mathrm{cm}^{-2}\right)\end{array}$ & $\begin{array}{l}\text { OCV } \\
(\mathrm{V})\end{array}$ & $\begin{array}{l}\text { Current } \\
\text { Density } \\
\left(\mathrm{mA} \mathrm{cm}^{-2}\right)\end{array}$ & $\begin{array}{l}\text { Peak Power } \\
\text { Density } \\
\left(\mathrm{mW} \mathrm{cm}^{-2}\right)\end{array}$ \\
$1 \mathrm{M}-1 \mathrm{M}$ & 0.89 & 167.7 & 44.3 & 0.84 & 226.0 & 53.8 \\
$1 \mathrm{M}-2 \mathrm{M}$ & 0.89 & 182.5 & 47.6 & 0.76 & 212.9 & 50.4 \\
$2 \mathrm{M}-1 \mathrm{M}$ & 0.87 & 217.9 & 47.4 & 0.84 & 166.4 & 43.4 \\
$2 \mathrm{M}-2 \mathrm{M}$ & 0.88 & 234.3 & 51.97 & 0.74 & 100.3 & 20.0 \\
$3 \mathrm{M}-3 \mathrm{M}$ & 0.88 & 229.7 & 45.9 & $* *$ & $* *$
\end{tabular}

** - Experiment not performed at this condition 


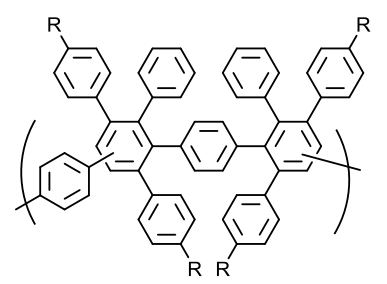

$\mathrm{R}=\mathrm{CH}_{3}$ or $\mathrm{CH}_{2} \mathrm{~N}^{+}\left(\mathrm{CH}_{3}\right)_{2} \mathrm{OH}^{-}$

ATMPP

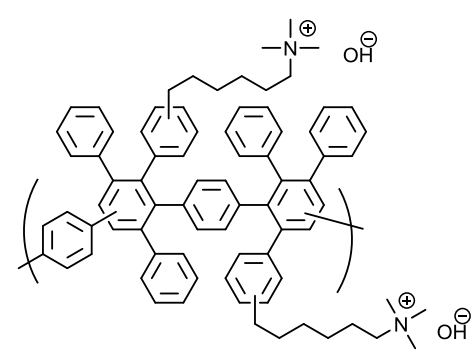

TMAC6PP

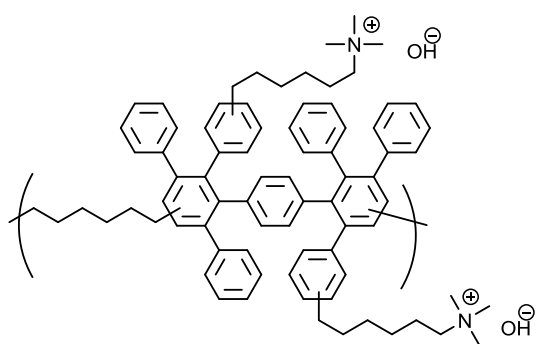

TMAC6PPC6

Figure 1. Structure of the polymers used in membranes and as ionomers in electrodes 


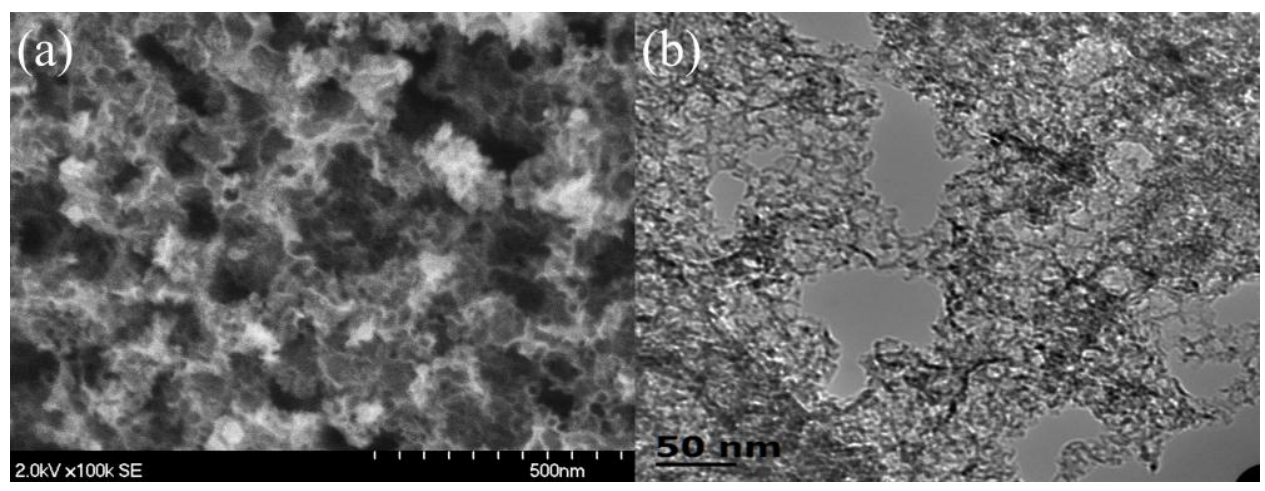

Figure 2. Images of best performing Fe-AAPyr-G1: a) SEM and b) TEM 


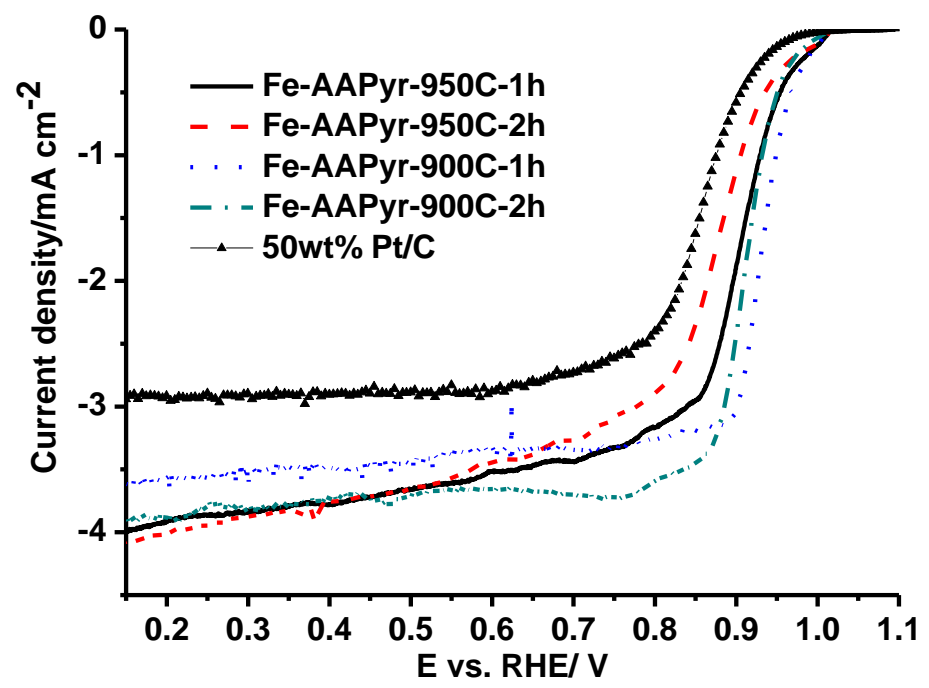

Figure 3. Electrochemical data for Fe-AAPyr-G1 catalysts with variation of heat treatment parameters in comparison with commercial $50 \mathrm{wt} \% \mathrm{Pt} / \mathrm{C}: \mathrm{T}=950{ }^{\circ} \mathrm{C}, \mathrm{t}=1 \mathrm{~h}(-), \mathrm{T}=950{ }^{\circ} \mathrm{C}, \mathrm{t}=2 \mathrm{~h}(-\mathbf{C}), \mathrm{T}=900{ }^{\circ} \mathrm{C}$, $\mathrm{t}=1 \mathrm{~h}(\cdots)$ and $\mathrm{T}=900{ }^{\circ} \mathrm{C}, \mathrm{t}=2 \mathrm{~h}(\boldsymbol{-}-)$, commercial 50wt\% Pt/C ( $\left.\boldsymbol{\Delta}-\right)$. Conditions: $1 \mathrm{M} \mathrm{KOH}$ saturated with $\mathrm{O}_{2}, 1200 \mathrm{RPM}, 5 \mathrm{mV} \mathrm{s}^{-1}$, catalyst loading $0.6 \mathrm{mg} \mathrm{cm}^{-2}$. 


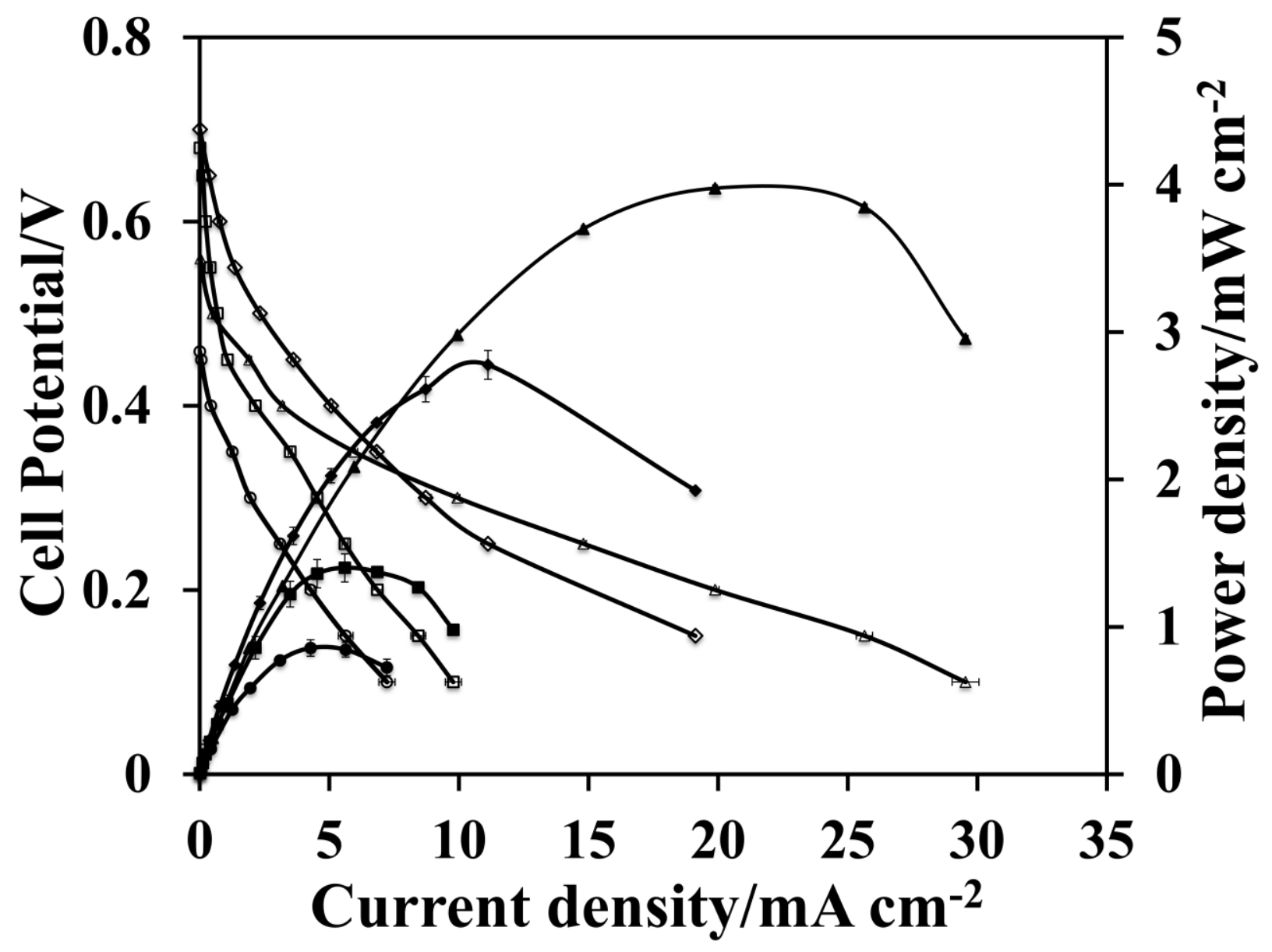

Figure 4. DMAFC performances of MEA-1 (Diamonds), MEA-2 (Circles) [9], MEA-3 (Squares), MEA-4 (Triangles) [9] in $1 \mathrm{M}$ methanol at $80{ }^{\circ} \mathrm{C}, 100 \% \mathrm{RH}$, polarization curves (open symbols), power curves (closed symbols). 


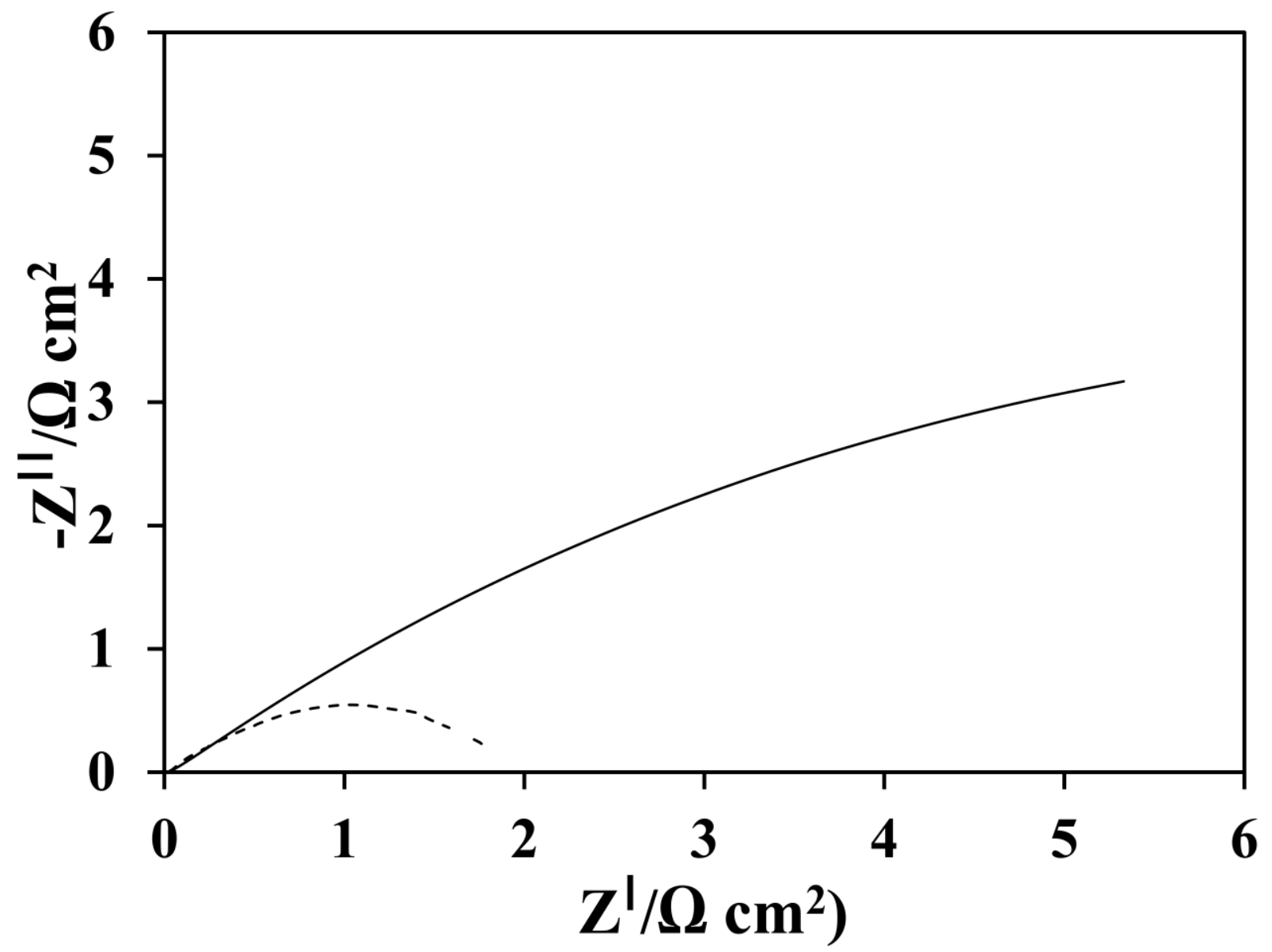

Figure 5. Impedance spectra of MEA-3 (-) and MEA-4 (----) [9] in 1M methanol at $400 \mathrm{mV}$, fuel cell operated at $80^{\circ} \mathrm{C}, 100 \% \mathrm{RH}$ 


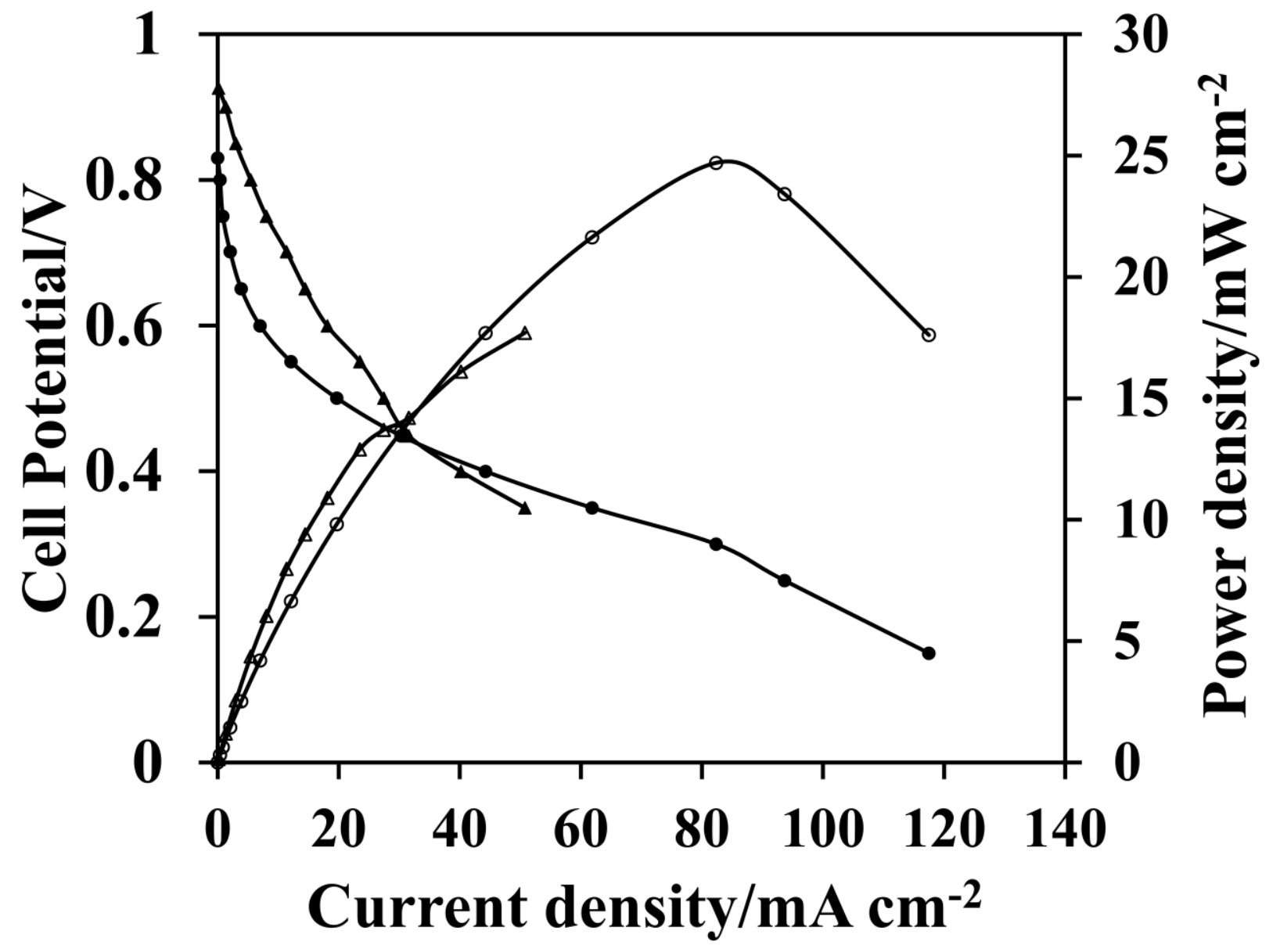

Figure 6. DMAFC performances of non-Pt cathode catalyst (MEA-1, circles) against a Pt cathode catalyst (MEA-2, triangles) [9] in $1 \mathrm{M}$ methanol and $1 \mathrm{M} \mathrm{KOH}$ at $80{ }^{\circ} \mathrm{C}, 100 \% \mathrm{RH}$ 


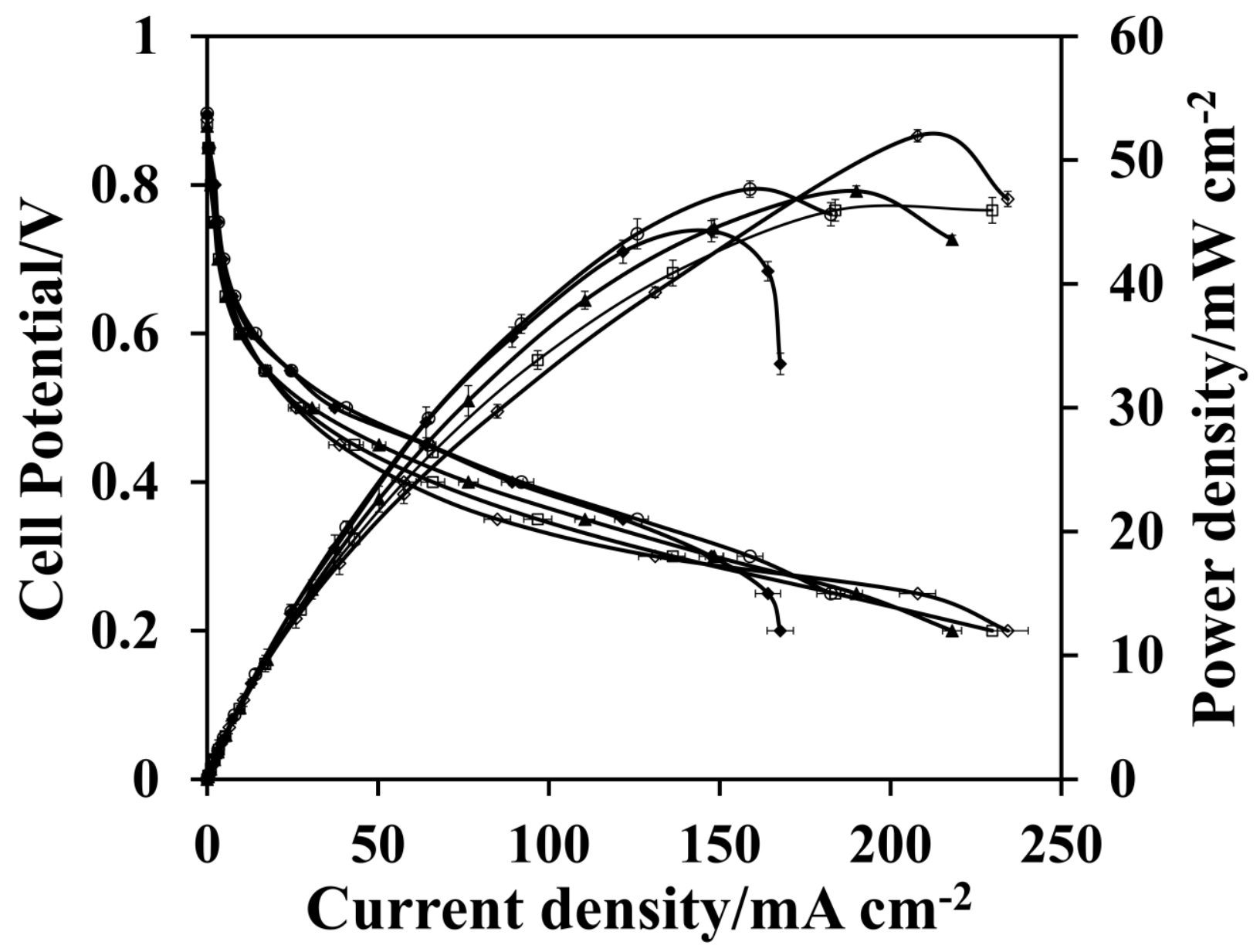

Figure 7. DMAFC performances of MEA-3 with UNM G-2 cathode catalyst as a function of fuel electrolyte concentrations (solid diamonds- $1 \mathrm{M}-1 \mathrm{M}$; triangles-2M-1M; circles- $1 \mathrm{M}-2 \mathrm{M}$; open diamonds2M-2M; squares- 3M-3M) 